\title{
Analysis and Assessment of the Wastewater Treatment Plant Operation in the City of Kłodzko
}

\author{
Tomasz Garbowski", Jacek Wiśniewski², Aleksandra Bawiec ${ }^{1}$ \\ 1 Institute of Environmental Engineering, Wroclaw University of Environmental and Life Sciences, \\ 50-363 Wroclaw, Grunwaldzki Square 24, Poland \\ 2 Faculty of Environmental Engineering, Wroclaw University of Science and Technology, 50-370 Wroclaw, \\ Wybrzeze Wyspianskiego 27, Poland \\ * Corresponding author's e-mail: tomasz.garbowski@upwr.edu.pl
}

\begin{abstract}
In this study, the current operation efficiency of the wastewater treatment plant (WWTP) in the city of Kłodzko in the Lower Silesia Voivodeship (Poland) was analyzed and the predicted amount of the wastewater flowing to the WWTP in a 20-year period (until the year 2036) was estimated. The data on the quality and the quantity of raw (entering to the WWTP) and treated sewage from the years 2012-2016 were analyzed. The five essential pollutants indicators: biochemical oxygen demand $\left(\mathrm{BOD}_{5}\right)$, chemical oxygen demand $\left(\mathrm{COD}_{\mathrm{Cr}}\right)$, total suspended solids (TSS), total nitrogen and total phosphorus, regulated in the water permit were used to evaluate the efficiency of contaminants removal. On the basis of the percentage reduction of the individual pollutants indicators and their acceptable concentrations in the treated sewage, the effectiveness of the operation of the object was determined. Furthermore, a so-called the treatment plant reliability factor $(R F)$ was calculated and its value below 1.0 indicates the correct operation of the wastewater treatment plant. After determining the prospective amount of raw sewage in 2036 (based on the decreasing population in the city) it has been found that the WWTP will work with a significant reserve of capacity and the modernization of the treatment system, leading to a decrease of its capacity should be considered.
\end{abstract}

Keywords: wastewater treatment systems, sewage treatment efficiency, WWTP, treatment plant reliability factor

\section{INTRODUCTION}

Currently, water is a valuable commodity, which is scarce in many places in the world. Thus, the protection of its resources is a serious challenge for the scientists, technologists and engineers. As emphasized by the Water Framework Directive, the issues related to rational and efficient water and wastewater management should be multidisciplinary [Arnell 2016, Castellet \& Molinos-Senante 2016]. World Health Organization (WHO) estimates, that up to $80 \%$ of illnesses and infections in the world result from inadequate treatment of sewage and thus insufficient amount of clean water. WHO also reports that more than 3.4 million of people die annually due to the activity of pathogens living in the aquatic environment [Ibrahim et al. 2014]. It can be said that water is a key component of the socio-economic develop- ment and keeps the environment in good condition. The wide interest in this international issue stimulates the development of the new wastewater treatment technologies [Castellet \& MolinosSenante 2016, Al-Zahiri 2015].

A modern WWTP must fulfill several basic tasks. Besides the effective removal of contaminants from the influent sewage, the reduction of greenhouse gasses emission, energy saving and the ability to reuse the part of resources such as the agricultural use of sewage sludge, must also be taken into account. In the other words, a modern WWTP should limit all kinds of emissions to the environment in order to protect it [Arnell 2016]. The untreated or insufficiently treated wastewater is a direct threat to the environment. Moreover, a discharge of untreated sewage into the receiving water body causes severe contamination resulting in eutrophication and intoxication of the aquatic 
organisms, as well as the chemical and biochemical transformations of pollutants causing the release of harmful gases disturbing the functioning of the ecosystems. All these factors cause a change in the biotic conditions and the physicochemical composition of wastewater receiver [Młyński et al. 2016a, Młyński et al. 2016b, Al-Zahiri 2015, Masłoń \& Tomaszek 2013].

Proper functioning of the WWTP is therefore required for an effective protection of the water resources against the pollution from sewers [Młyński et al. 2016a, Młyński et al. 2016b, Łagożny et al. 2015, Bugajski \& Mielenz 2008]. Determining the efficiency of work of the WWTP is challenging task, mainly due to the uncontrolled fluctuations in the composition of sewage, incessantly flowing in to the treatment plant throughout the year. Furthermore, such an object cannot be completely shut down in order to carry out inspection or renovation. Ultimately, connection of each individual processes by the use of recirculation makes this technological system an inseparable complex wherein a disturbance of one process affects the efficiency of the whole treatment plant [Arnell 2016].

Considering the above, it can be concluded that the mathematical models and simulations, which prognostically estimate the effects of the operation of the designed technological system for the wastewater treatment, are good methods to determine the operation of WWTPs. The choice of the appropriate sewage treatment method requires the quantitative and qualitative analysis of influent wastewater, the effectiveness of the adopted technology and the economic aspects [Arnell 2016, Castellet \& Molinos-Senante 2016, Łagożny et al. 2015, Bugajski 2014]. Improper selection of the technology and dimensions of the treatment plant can result in subsequent high operating costs, inadequate efficiency of wastewater treatment and thus, the failure to meet the requirements of the water permit which entails the financial penalties imposed on the wastewater treatment facilities [Młyński et al. 2016b].

It is notable that according to Regulation of the Minister of Environment ${ }^{1}$, nutrients (nitrogen and phosphorus) are not limited in the sewage discharged from the WWTP with Equivalent Num-

\footnotetext{
Regulation of the Minister of Environment of 18 November 2014 on the conditions to be met when discharging sewage into water or soil, and on the substances particularly harmful to the aquatic environment (Journal of Laws of 2014, item 1800).
}

ber of Inhabitants $(E N I) \leq 9999$. Therefore, at the stage of design these facilities, both the actual and the prospective number of sewage producers should be precisely determined, in order to avoid exceeding the permissible values of the indicators in the outflow to the receiving water body, while minimizing the cost of the treatment processes.

The paper presents the effectiveness of the WWTP in the city of Kłodzko on the basis of the quarterly data concerning the composition of the untreated and treated sewage from the five-year period (2012-2016). In addition, based on the perspective of the population, the amount of the sewage entering the treatment plant was estimated for the next 20 years (up to 2036) and thus the effectiveness of the treatment plant in the future years was determined.

\section{CHARACTERISTICS OF THE OBJECT ${ }^{2}$}

The wastewater treatment plant in the city of Kłodzko works in the mechanical and biological system of the sewage treatment. Wastewater which flows into the treatment plant is drained by the sewage system from the city area and is also transported by sewage trucks from the cesspools located in rural areas. The currently existing facility was built in 1991 and is owned by the company "Wodociągi Kłodzkie Sp. z o.o.". The WWTP was rebuilt after a natural disaster that took place in 1997, when a huge flood occurred, covering the territory of Poland, Germany and the Czech Republic. The current capacity of the treatment plant is $12500 \mathrm{~m}^{3} \cdot \mathrm{d}^{-1}$ for the biological part and 25000 $\mathrm{m}^{3} \cdot \mathrm{d}^{-1}$ for the mechanical part. In the design assumptions, the WWTP is adapted to receive the sewage from the Equivalent Number of Inhabitants equal to 62500 .

The technological layout of the treatment plant consists of five stages. The first stage of treatment processes are the stepped bars with $3.0 \mathrm{~mm}$ spacing and the capacity of approximately $2400 \mathrm{~m}^{3} \cdot \mathrm{h}^{-1}$. The screenings that are created by the separation of the solid parts from sewage are dewatered by using a piston press and then exported to a compost pile outside the treatment plant. Afterwards, the sewage is transported to the horizontal grit chambers. The sand collected in sludge concentrator is directed to the process of dewatering and then

\footnotetext{
2 The information for this chapter has been obtained from the sources of the WWTP in the city of Kłodzko.
} 
also transported to the compost pile. The next element is the primary settling tank, which removes $60-70 \%$ of the total suspended solids and about $30 \%$ of $\mathrm{BOD}_{5}$. The sludge created in the primary settling tank is subjected to an acid fermentation and constitutes a source of volatile fatty acids for the Enhanced Biological Phosphorus Removal (EBPR) process [Randall et al. 1998]. The main part of the WWTP is a horizontal flow biological reactor, where sewage is treated using the activated sludge technology. The total capacity of the reactor is 5800 $\mathrm{m}^{3}$ and the active depth is $3.20 \mathrm{~m}$. The reactor can be operated in the Modified University of Cape Town (MUCT) system, which is shown in Figure 1. This system enables to remove nitrogen and phosphorus in the summer.

When the concentration of ammonium nitrogen increases in the treated sewage, the reactor, due to the control of the aeration, is switched to the 3-stage Modified Bardenpho (A2/O) system with enlarged oxygen zone. This enables to intensify the nitrification process and thus increase the reduction of ammonium nitrogen. The diagram of the A2/O system is shown in Figure 2.

In the winter, when the temperature of sewage drops to $10-12^{\circ} \mathrm{C}$ and the biological removal of nitrogen is slowed down, the treatment plant focuses on the EBPR process using the Phoredox (A/O) system (Figure 3), excluding the denitrification chamber and enlarging the oxygen zone.

The last element of the wastewater treatment system in the city of Kłodzko is the secondary settling tank. It fulfills the same role as in any treatment plant with activated sludge. A part of the sludge separated in the secondary settling tank is recycled (as external recirculation) to the biological reactor and the remaining part of the sludge is pumped to the primary settling tank, whence it is transported with the primary sludge to the system of sewage sludge processing. The most important element of this system is a solar sludge dryer. The treated sewage is discharged into the Nysa Kłodzka river with a sewer line with a diameter of $120 \mathrm{~cm}$.

\section{METHODOLOGY OF RESEARCH}

In order to conduct the analysis of the actual efficiency of the wastewater treatment operation, the data on the composition of raw and treated sewage were used in the scope of basic quality indicators of wastewater regulated in the water permit and Regulation of the Minister of Environment namely: $\mathrm{BOD}_{5}, \mathrm{COD}_{\mathrm{Cr}}$, total suspended solids, total nitrogen and total phosphorus. The collected data covered a period of 5 years, from 2012 to 2016.

The concentrations of the individual pollutants indicators in the treated sewage and the reduction rates of these indicators were compared with the water permit issued in 2003 for a definite time (until the year 2019) which allows discharging wastewater to the receiver in the amount of $12500 \mathrm{~m}^{3} \cdot \mathrm{d}^{-1}$. The water permit enables to fulfill of one of the two requirements for the quality of treated sewage: the maximum

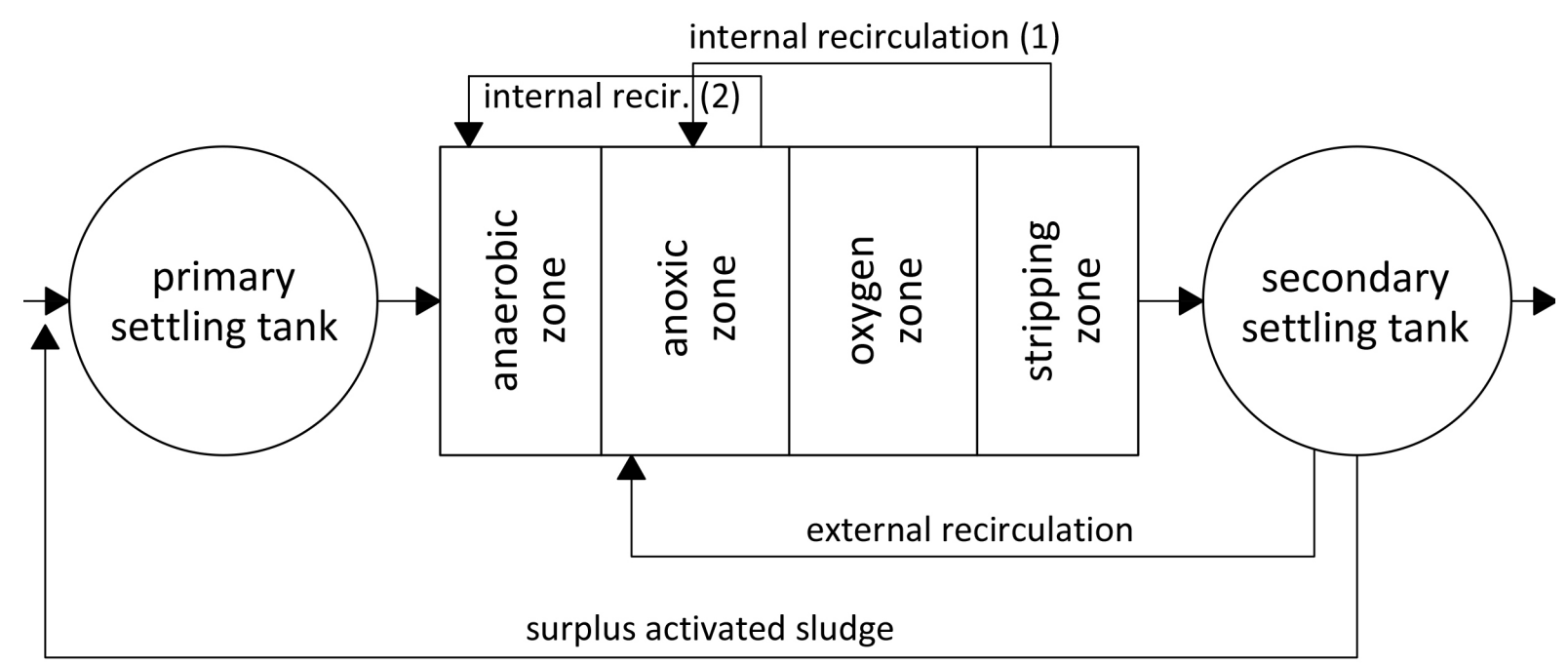

Figure 1. The scheme of the MUCT system of biological reactor in the WWTP in the city of Kłodzko 


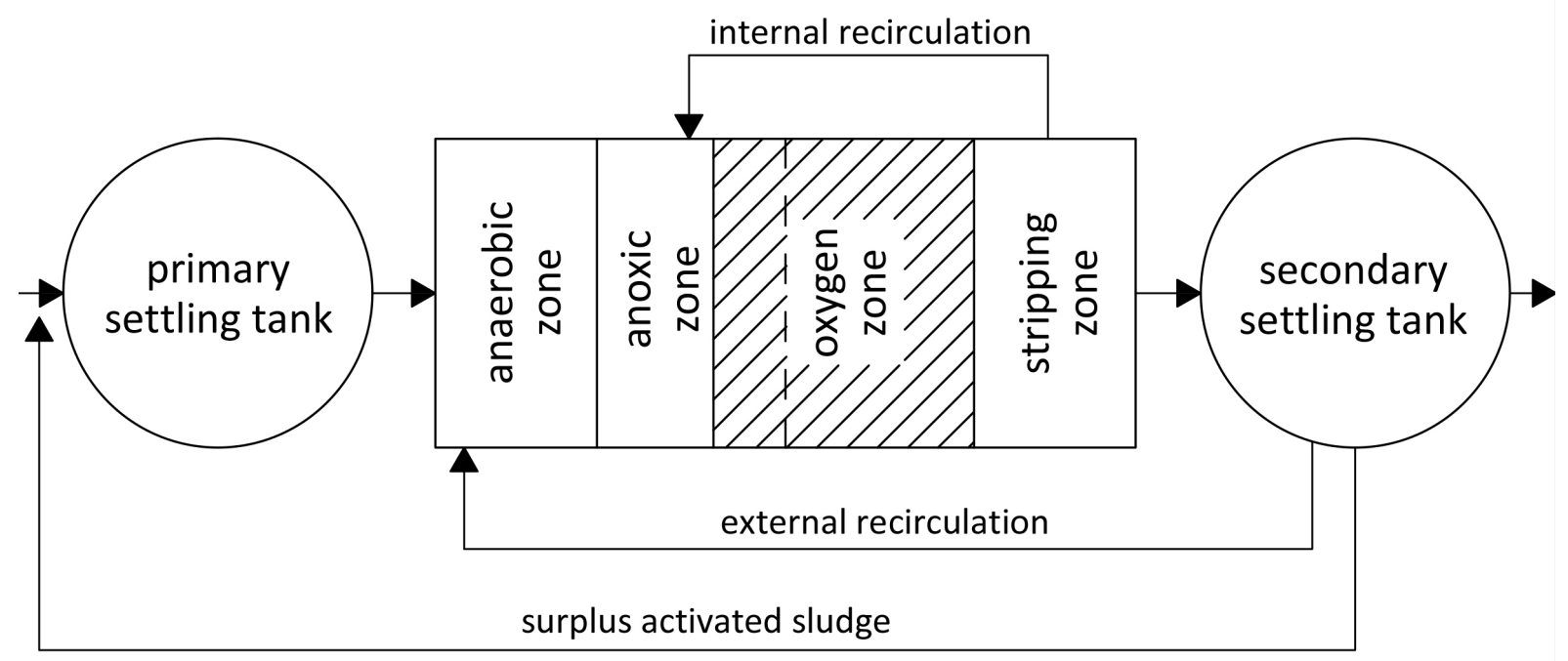

Figure 2. The scheme of the A2/O system with enlarged oxygen zone of biological reactor in the WWTP in the city of Kłodzko

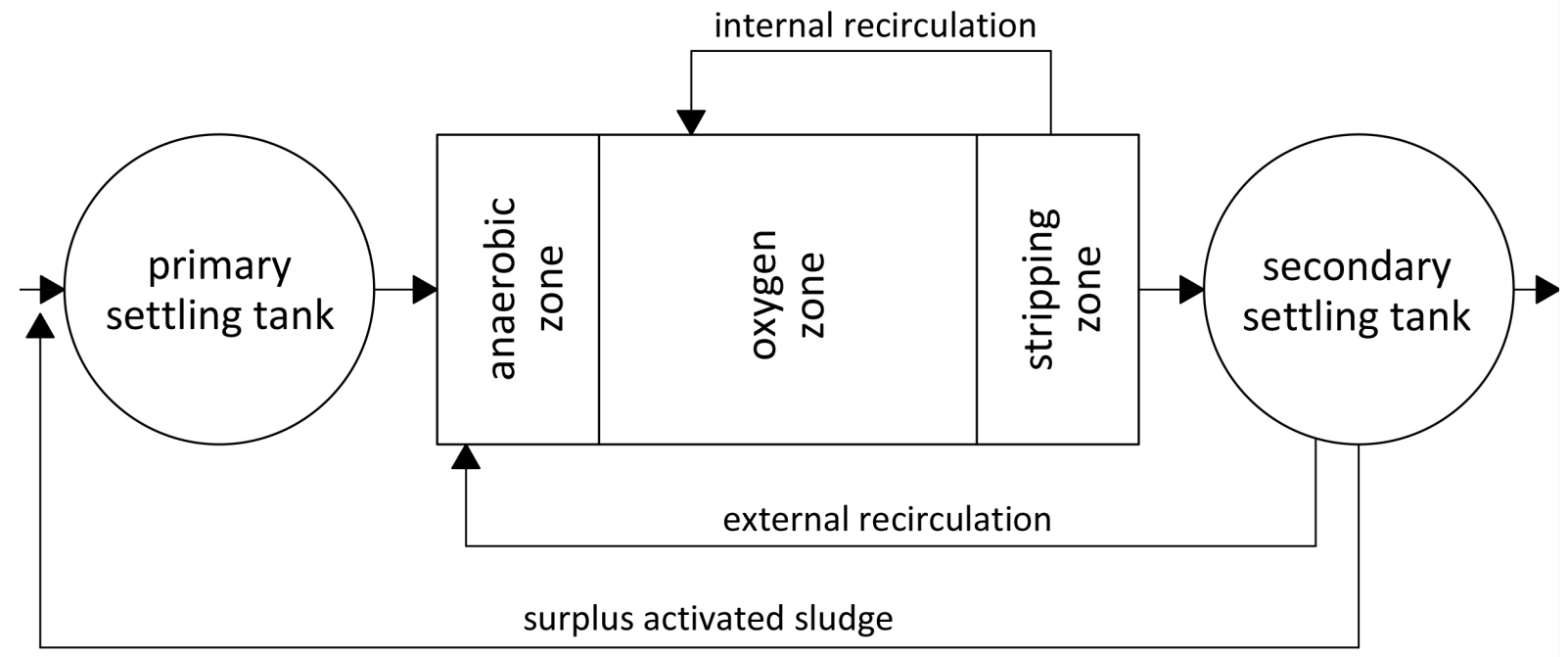

Figure 3. The scheme of the A/O system without anoxic zone of biological reactor in the WWTP in the city of Kłodzko

concentration of the indicator or the minimum level of reduction for the incoming effluent. The permissible values of the individual pollutants indicators and the required minimum reduction rates according to the water permit are shown in Table 1.

In order to determine the actual efficiency of the treatment plant operation, the actual value of the ENI was calculated, based on the total $\mathrm{BOD}_{5}$ loading rate in sewage inflowing in 2016 and the unitary $\mathrm{BOD}_{5}$ loading rate, based on art. 43 of the Water Law Act ${ }^{3}$. The calculations were performed using the Eq. (1).

3 The Water Law Act of 18 July 2017 (Journal of Law 2001, No. 115, item 1229).

$$
E N I=\frac{T L R_{B O D 5}}{U L R_{B O D 5}}
$$

where: $E N I$ - Equivalent Number of Inhabitants $T L R_{\text {BOD } 5}$ - total $\mathrm{BOD}_{5}$ loading rate (in 2016), $\mathrm{g} \cdot \mathrm{d}^{-1}$

$U L R_{B O D 5}$ - unitary $\mathrm{BOD}_{5}$ loading rate, 60 $\mathrm{g} \cdot$ capita $^{-1} \cdot \mathrm{d}^{-1}$

The paper also gives the value of the treatment plant reliability factor $(R F)$ which was calculated as the quotient of the average concentration of an individual pollutant indicator in the treated sewage and its permissible value in the wastewater discharged to the receiver, Eq. (2) [Młyński et al. 2016b, Miernik \& Wałęga 2006]. 
Table 1. The required parameters of the treated sewage in accordance with the water permit issued for the WWTP in the city of Kłodzko

\begin{tabular}{|l|c|c|}
\hline The quality indicators in sewage & $\begin{array}{c}\text { The permissible concentration in treated } \\
\text { sewage }\left[\mathrm{mg} \cdot \mathrm{dm}^{-3}\right]\end{array}$ & The minimum percentage reduction [\%] \\
\hline $\mathrm{BOD}_{5}$ & 15.0 & 90.0 \\
\hline $\mathrm{COD}_{\mathrm{Cr}}$ & 125.0 & 75.0 \\
\hline Total nitrogen & 15.0 & 80.0 \\
\hline Total phosphorus & 2.0 & - \\
\hline Total suspended solids & 35.0 & 90.0 \\
\hline
\end{tabular}

$$
R F=\frac{\bar{x}}{x_{p e r}}
$$

where: $\bar{x}$ - the average concentration of a pollutant indicator in the treated sewage, $\mathrm{mg}$ $\mathrm{dm}^{-3}$

$x_{p e r}-$ the permissible concentration of a pollutant indicator in the treated sewage, $\mathrm{mg} \mathrm{dm}{ }^{-3}$

Apart from analyzing the current operation of the WWTP, the prospective capacity of this facility was calculated based on the estimation of the amount of the inflowing municipal wastewater in the 20-year perspective (until the year 2036). The first step to assess the amount of sewage influent to the treatment plant was determination of the prospective population in 2036. The calculation was based on the equation of the trend line from the population change chart in the city of Kłodzko in the years 1995-2016 (Figure 9) ${ }^{4}$. Then, taking the average daily flow of sewage per capita of $188.36 \mathrm{dm}^{3} \cdot$ capita $^{-1} \cdot \mathrm{d}^{-1}$ as a constant value, the prospective amount of the sewage discharged from the city area to the WWTP in 2036 was calculated. The method of calculation of the average unitary wastewater flow is described in the final part of the paper.

\section{RESULTS AND ANALYSIS}

\section{Analysis of the current operation of waste- water treatment plant in the city of Kłodzko}

The amount of the sewage influent to the treatment plant varies in respective quarters and years. Over five years which have been analysed, the values of the raw sewage flow fluctuated in range $4133-7894 \mathrm{~m}^{3} \cdot \mathrm{d}^{-1}$. On the basis of the quarterly and the average annual amounts of

\footnotetext{
4 Central Statistical Office of Poland, Local Data Bank, data as of 10th May, 2017.
}

the sewage inflowing to the treatment plant, it can be stated that the fluctuations of sewage inflow are caused by a variable quantity of the rainwater and the meltwater which go to the treatment plant through the combined sewerage. Variable weather conditions could have a significant impact on the amount of pollutants present in the wastewater [Strzelczyk et al. 2012]. By comparing the actual average annual volumetric flow rate of raw sewage with the designed capacity of the treatment plant $\left(12500 \mathrm{~m}^{3} \cdot \mathrm{d}^{-1}\right.$ for the biological treatment and $25000 \mathrm{~m}^{3} \cdot \mathrm{d}^{-1}$ for the mechanical treatment) it is clearly noticeable that the facility works with a significant reserve of the capacity which should be reduced in order to avoid the excess operating costs. The quality of the wastewater influent to the WWTP and treated sewage was analysed on the basis of Figures 4-8.

As can be seen from Figure 4, the concentration of $\mathrm{BOD}_{5}$ in the raw sewage exceeds the permissible value $\left(15.0 \mathrm{mg} \cdot \mathrm{dm}^{-3}\right.$ according to the water permit) which indicates the necessity of removing the organic pollutants susceptible to biological decomposition. At the turn of 2015/2016, the largest increase of $\mathrm{BOD}_{5}$ in the sewage inflowing to the WWTP was observed. It is associated with the decreasing amount of sewage and inconsiderable addition of rainwaters in the combined sewage which did not cause a significant dilution of domestic wastewater that contains high concentrations of organic compounds. After the treatment process, the wastewater discharged to the receiver met the standards, both in terms of the concentration of pollutants and their percentage of reduction. It is noteworthy that the smallest values for biochemical oxygen demand in treated sewage usually occurred in the third quarter of the year. It is connected with the highest efficiency of the biological treatment process with the participation of microorganisms in activated sludge which exhibit the greatest activity in the summer time [Miksch \& Sikora 2010, Sadecka 2010]. The maximum value of $\mathrm{BOD}_{5}$ in raw sew- 


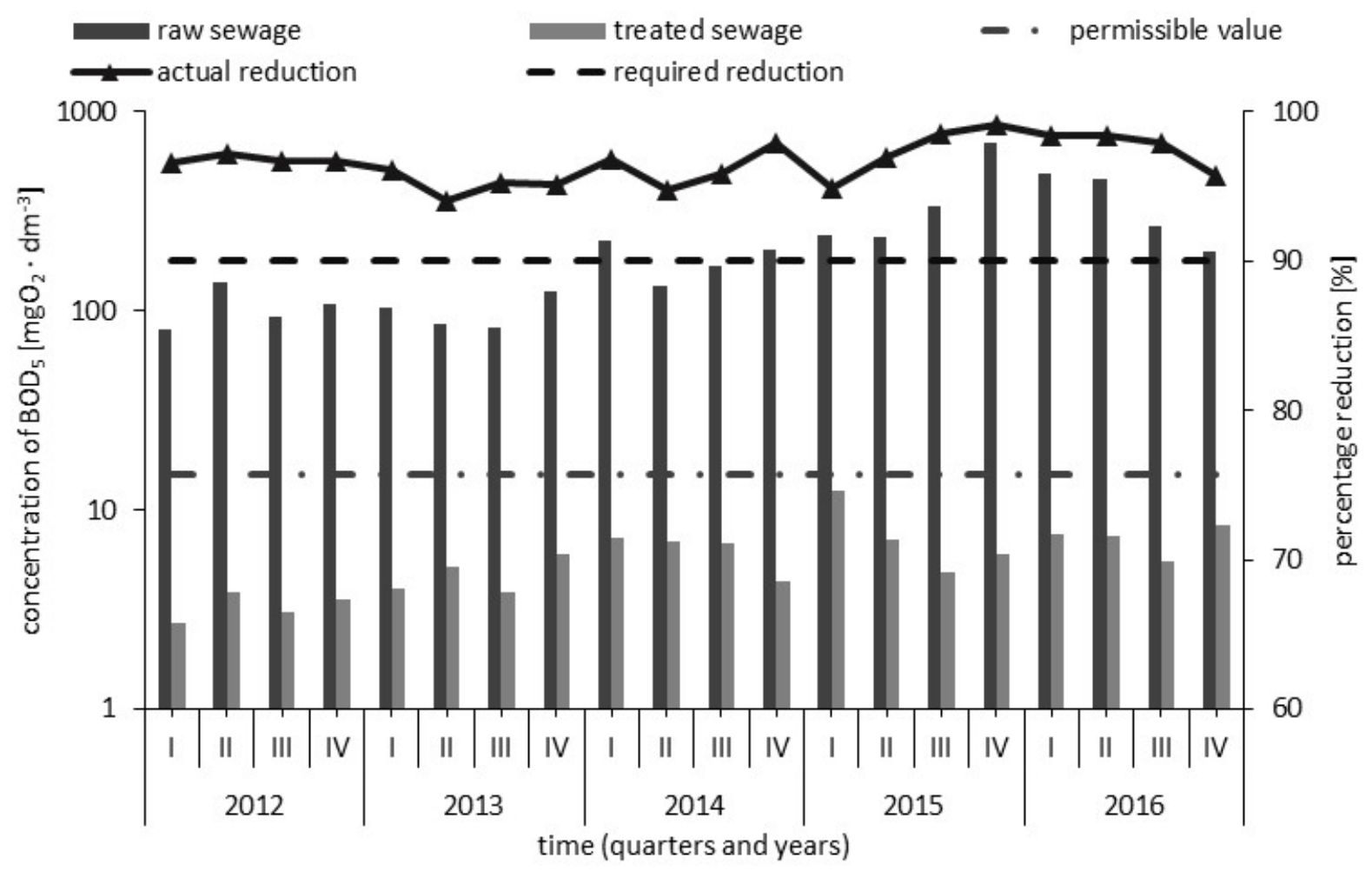

Figure 4. The changes in the concentration of $\mathrm{BOD}_{5}$ in the raw and treated sewage in the individual quarters, the permissible value, as well as the required and actual percentage reduction

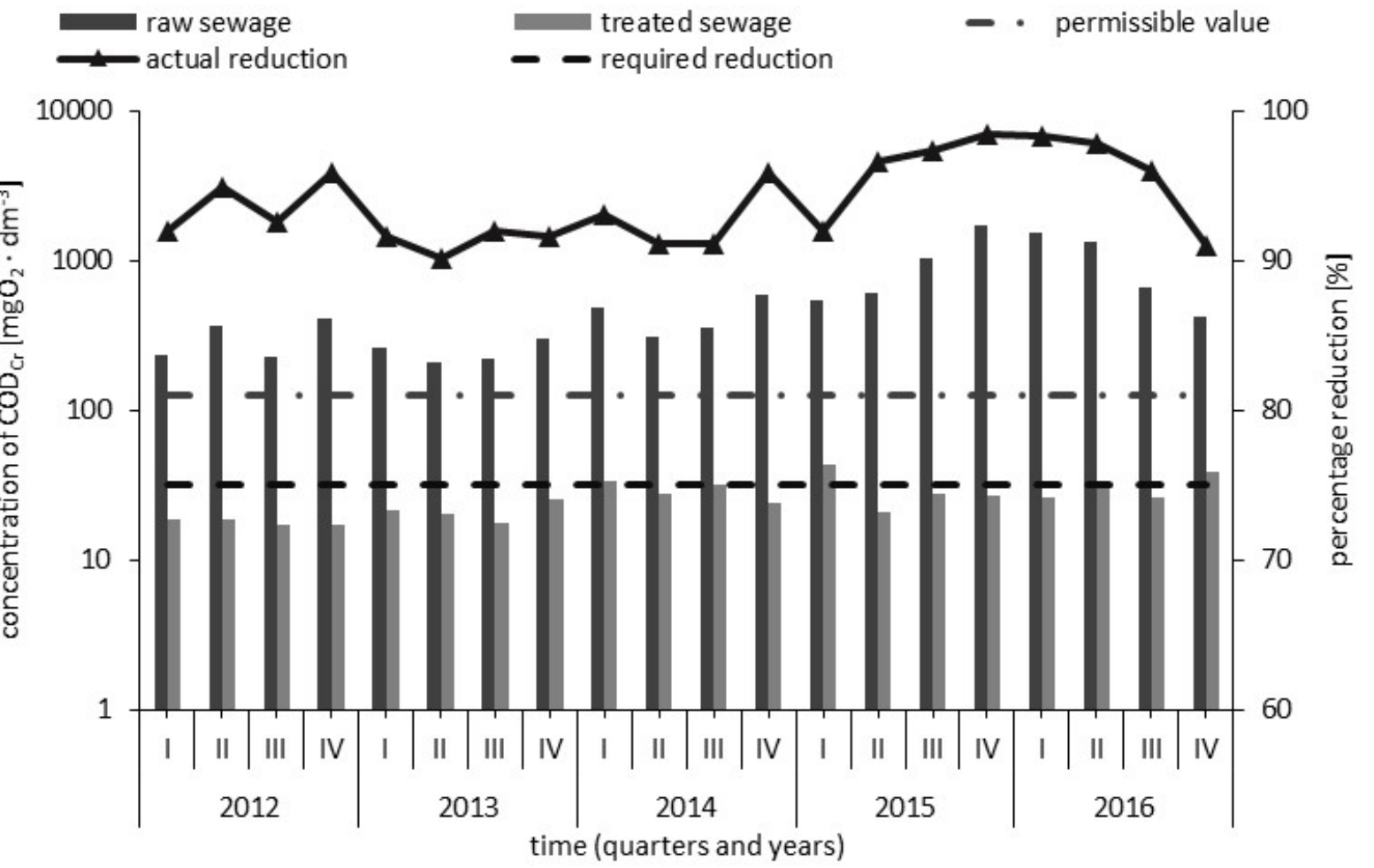

Figure 5. The changes in the concentration of $\mathrm{COD}_{\mathrm{Cr}}$ in the raw and treated sewage in the individual quarters, the permissible value, as well as the required and actual percentage reduction 


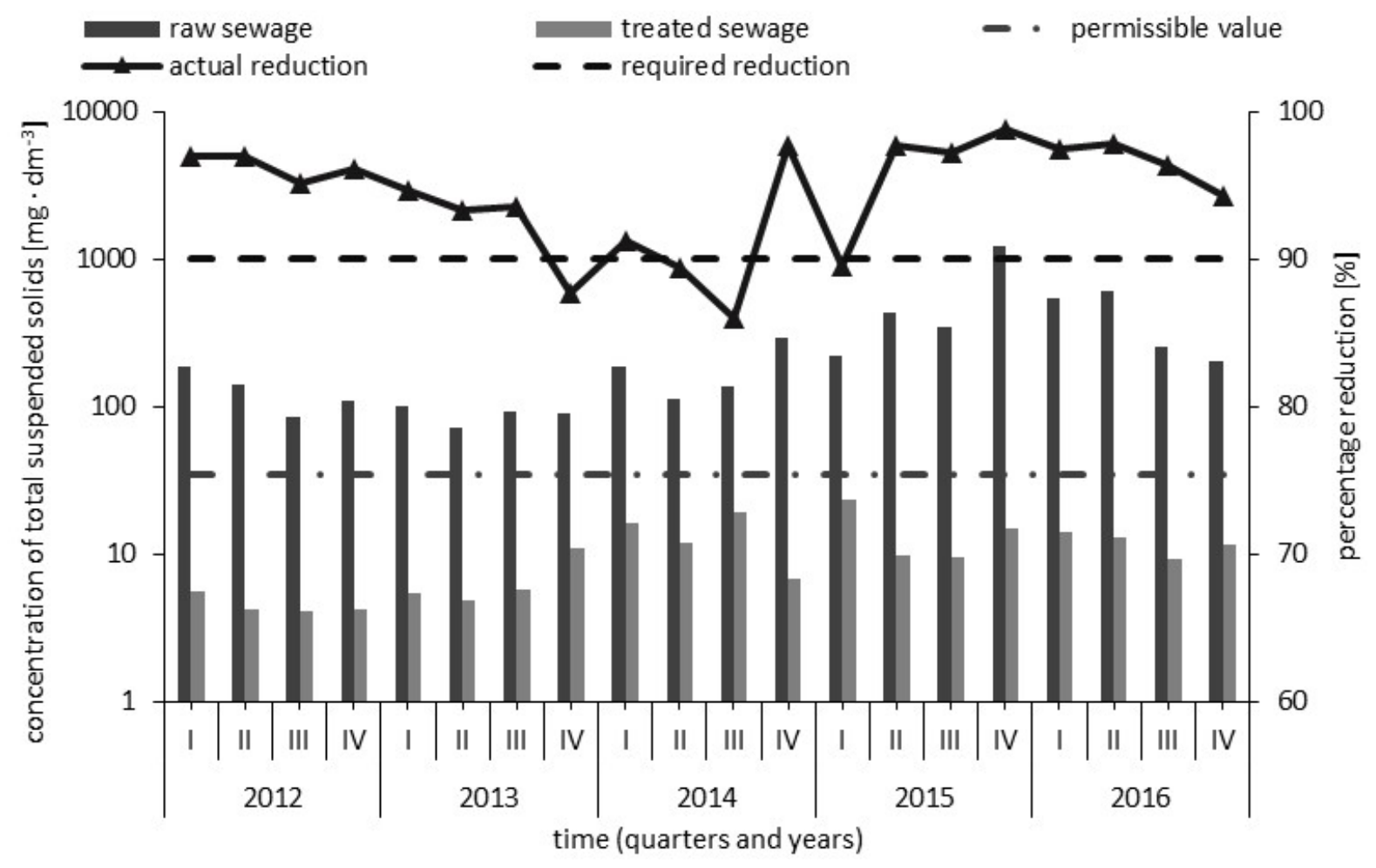

Figure 6. The changes in the concentration of total suspended solids in the raw and treated sewage in the individual quarters, the permissible value, required and actual percentage reduction

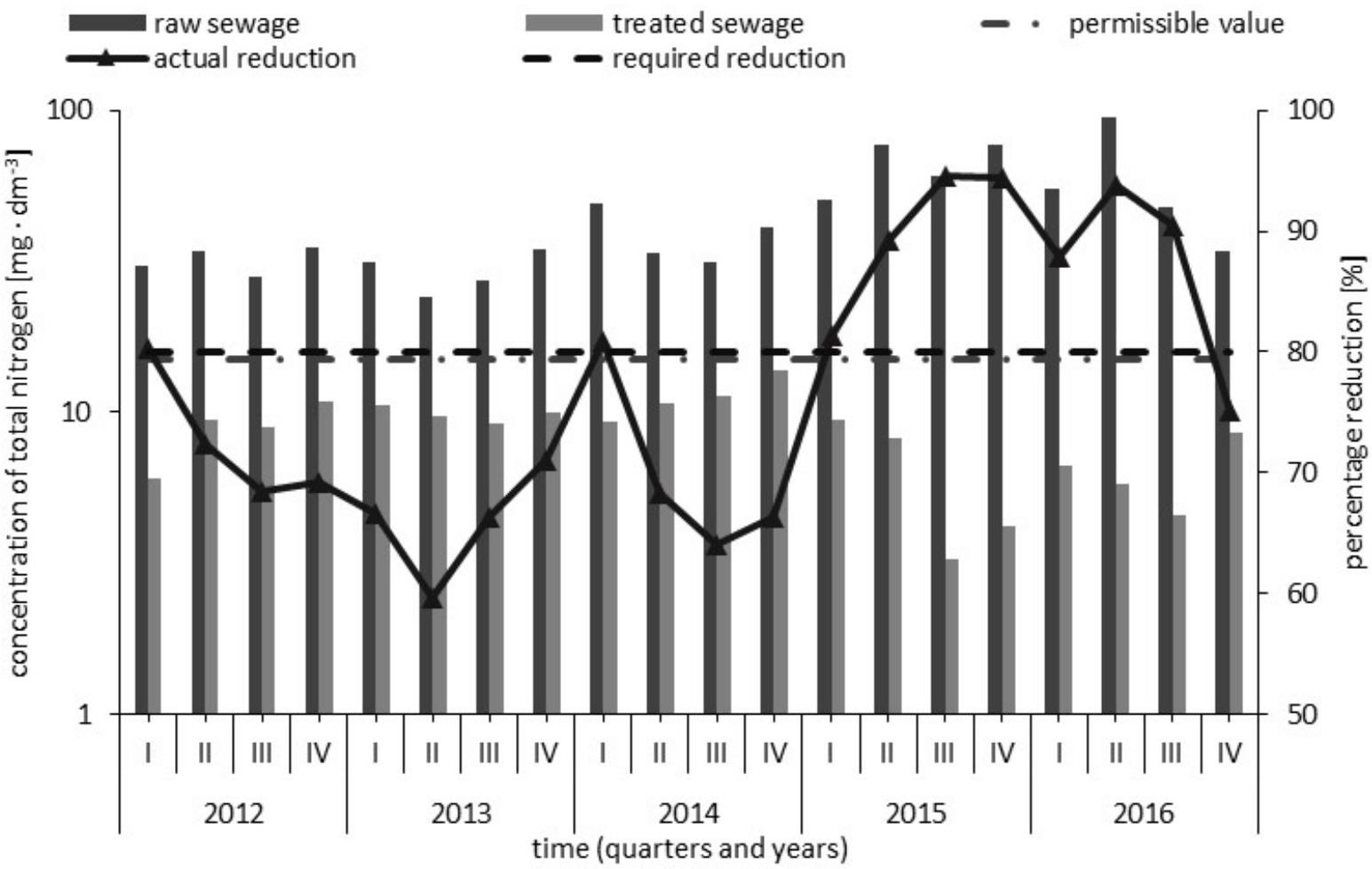

Figure 7. The changes in the concentration of total nitrogen in the raw and treated sewage in the individual quarters, the permissible value, as well as the required and actual percentage reduction 


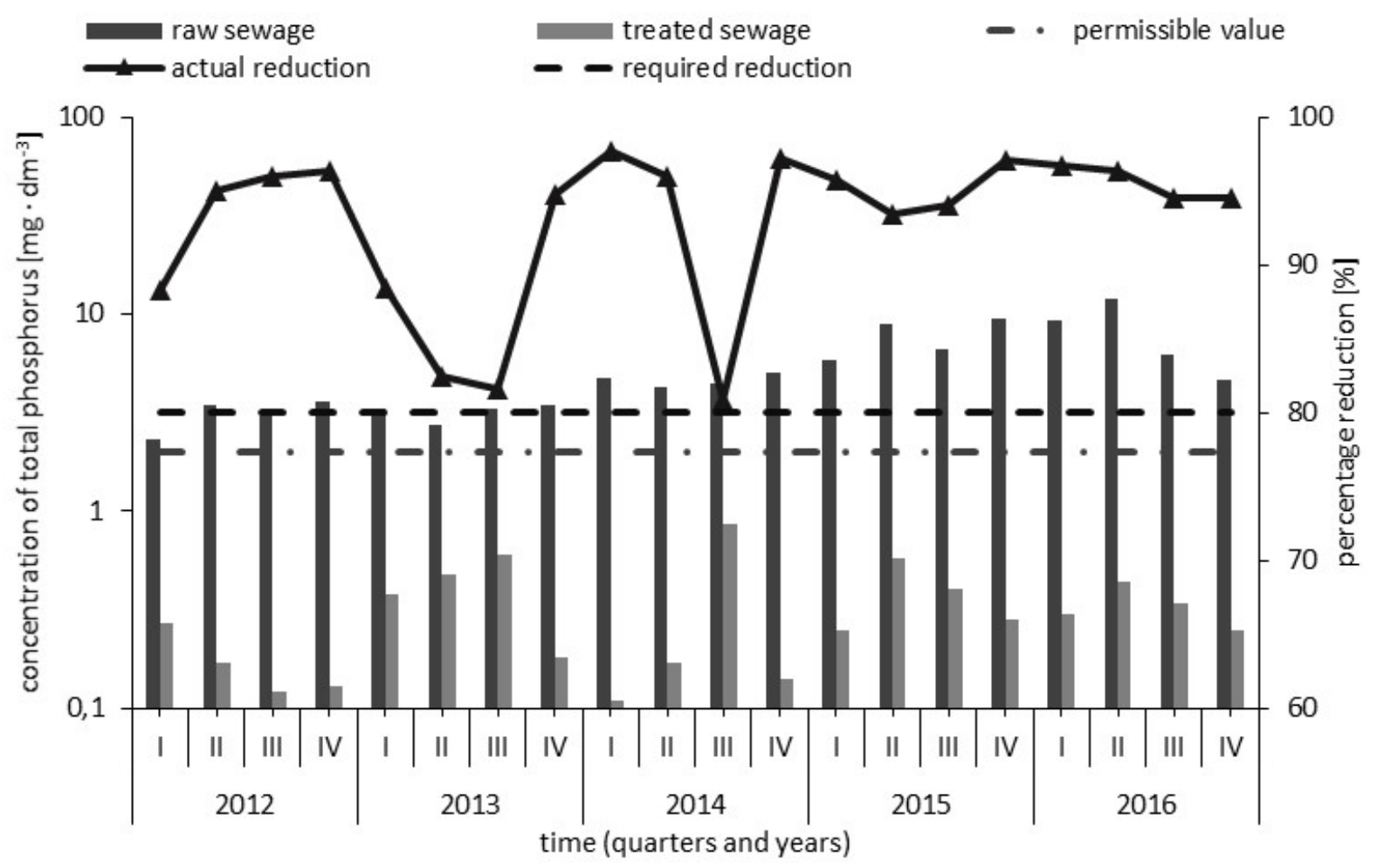

Figure 8. The changes in the concentration of total phosphorus in the raw and treated sewage in the individual quarters, the permissible value, as well as the required and actual percentage reduction

age reached $689.25 \mathrm{mg} \cdot \mathrm{dm}^{-3}$ and the minimum was $81.80 \mathrm{mg} \cdot \mathrm{dm}^{-3}$. In relation to treated sewage, the concentration of $\mathrm{BOD}_{5}$ fluctuated in the range of $2.72-12.42 \mathrm{mg} \cdot \mathrm{dm}^{-3}$ and the average value reached $5.85 \mathrm{mg} \cdot \mathrm{dm}^{-3}$. It was 2.5 times less than the permissible value.

The indicator of chemical oxygen demand is subjected to similar changes as $\mathrm{BOD}_{5}$. Therefore, also in this case, an increase of this indicator in raw sewage was observed in the years 2015-2016. The concentration of organic compounds which is characterized by $\mathrm{COD}_{\mathrm{Cr}}$ exceeds the permissible value $\left(125.0 \mathrm{mg} \cdot \mathrm{dm}^{-3}\right)$ in the sewage influent to the WWTP in each quarter of the whole 5-year period. High efficiency of organic contaminants removal in the biological treatment process contributes to more than $90 \%$ reduction of $\mathrm{COD}_{\mathrm{Cr}}$ and thus met the permissible value of percentage reduction which is $75 \%$. In the raw sewage, the values for $\mathrm{COD}_{\mathrm{Cr}}$ ranged between 205.28-1694.62 $\mathrm{mg} \cdot \mathrm{dm}^{-3}$ and through the treatment process, the sewage discharged to the receiver was characterized by low value of $\mathrm{COD}_{\mathrm{Cr}}$ that ranged from 16.98 to $42.70 \mathrm{mg} \cdot \mathrm{dm}^{-3}$ with the average value $25.53 \mathrm{mg} \cdot \mathrm{dm}^{-3}$.

Figure 6 shows the concentration of the total suspended solids in raw and treated sewage. The highest value of this indicator in the waste- water flowing into the WWTP was observed in the IV quarter of 2015 and amounted to 1227.90 $\mathrm{mg} \cdot \mathrm{dm}^{-3}$, whereas in the treated sewage, the highest concentration of TSS was noted in the I quarter of the same year $\left(23.25 \mathrm{mg} \cdot \mathrm{dm}^{-3}\right)$ and it was lower than the permissible value by approximately $34 \%$. Comparing the fluctuations of the concentration of total suspended solids with the charts for $\mathrm{BOD}_{5}$ and $\mathrm{COD}_{\mathrm{Cr}}$, a similar trend was observed in the increase of these parameters in raw sewage at the turn of 2015/2016. Moreover, the correlation between the changes in the concentration of $\mathrm{BOD}_{5}$ and TSS in the sewage entering the treatment plant should be noted. This correlation indicates the participation of large amounts of biodegradable particles which affect increase in the value of the biochemical oxygen demand in whole volume of suspended solids. Therefore, the removal of suspension during the mechanical treatment process contributes to partial reduction of $\mathrm{BOD}_{5}$. The percentage reduction of the suspended solids fluctuated considerably during the analysed 5-years period and did not always reach the required value of $90 \%$. However, as the standard for the permissible concentration of TSS in treated sewage were met, it could be stated that in this regard, the treatment plant works properly. 
Total nitrogen is the subsequent parameter which characterizes the quality of sewage . Figure 7 shows the concentration of this component in the raw and treated sewage, and the degree of nitrogen reduction as a result of the treatment processes. As in the case of previous parameters, due to the decreasing amount of the municipal wastewater, the concentration of total nitrogen in the sewage influent to the treatment plant increased in the 2015 and 2016 and reached the maximum value of $94.48 \mathrm{mg} \cdot \mathrm{dm}^{-3}$. The permissible concentration of total nitrogen in the treated sewage is $15.0 \mathrm{mg} \cdot \mathrm{dm}^{-3}$. This concentration was not exceeded in any quarter of the year and the maximum value of concentration of total nitrogen in treated sewage was $13.80 \mathrm{mg} \cdot \mathrm{dm}^{-3}$. In the chart, the low degree of reduction of nitrogen should be noted. Only in the two quarters between 2012 and 2014, the minimum value of the $80 \%$ of reduction was achieved. However, in the case of meeting the standards concerning the permissible concentration of pollutants in the treated sewage, the requirement of achieving the requisite percentage reduction is not mandatory. It is noteworthy that in the 2015-2016, despite the high concentrations of total nitrogen in the sewage influent to the treatment plant, the degrees of reduction were the highestł thereby, the lowest concentrations of this component in treated sewage were noted. During this period, total nitrogen was reduced even to the value of $3.29 \mathrm{mg} \cdot \mathrm{dm}^{-3}$ in the wastewater discharged to the receiver. A high efficiency of ammonium nitrogen removal in the $\mathrm{A} 2 / \mathrm{O}$ system influenced the limitation of total nitrogen concentration in the sewage. The ammonium nitrogen constituted the predominant part in the influent total nitrogen.

The reason of a small reduction of total nitrogen in the first three analysed years could be the insufficient concentration of the organic compounds at the biological reactor inlet. These compounds limit the growth of the bacterial biomass in the activated sludge and thus limit the reduction of nitrates to molecular nitrogen in the denitrification process [Sadecka 2010]. This can be confirmed by Fig. 4, which shows that the concentration of $\mathrm{BOD}_{5}$ in raw sewage in the 2012 and 2013 was lower than in the two consecutive years. Therefore, in order to achieve a high efficiency of total nitrogen removal, the efficiency of the organic contaminants removal should be appropriately balanced, relative to the required effects of the reduction of nutrients in the treated sewage.
The last analysed parameter which describes the composition of sewage is total phosphorus. Figure 8 shows that the WWTP operates with high efficiency in respect to the removal of this component. The lowest concentration of phosphorus in the raw sewage was $2.32 \mathrm{mg} \cdot \mathrm{dm}^{-3}$ and the highest, which occurred in the II quarter of 2016 was $12.06 \mathrm{mg} \cdot \mathrm{dm}^{-3}$. The highest concentration of phosphorus in the treated sewage was more than $50 \%$ lower than the permissible value $(2.0$ $\mathrm{mg} \cdot \mathrm{dm}^{-3}$ ) and reached $0.85 \mathrm{mg} \cdot \mathrm{dm}^{-3}$ and the lowest value was only $0.11 \mathrm{mg} \cdot \mathrm{dm}^{-3}$. The percentage of phosphorus reduction was also significantly high in most quarters (over 90\%), and did not decrease below the minimum value of $80 \%$ during the whole 5-year period. Such high efficiency in relation to phosphorus removal demonstrates the proper functioning of the EBPR process. However, the treatment plant is prepared for a sudden increase of the phosphorus concentration in the inflowing sewage, through the possibility of activating the chemical precipitation of the phosphorus excess by appropriate dosage of coagulants. Apart from the analysis above, the values of the treatment plant reliability factor presented in Table 2 also indicate the proper operation of WWTP in the city of Kłodzko.

The values of the treatment plant reliability factor below 1.0 confirm the proper operation of WWTP in relation to individual indicators of pollutants. In addition, the average values of each indicator were significantly lower than the permissible value. The analysed values of the $R F$ coefficient show that the treatment plant has the highest effectiveness in relation to total phosphorus removal which is also confirmed by the data presented in Figure 8.

\section{Analysis of prospective operation of waste- water treatment plant in the city of Kłodzko}

The amount of the generated municipal wastewater is closely related to the population in the area of treatment plant supply. According to the data of Central Statistical Office of Poland, in the city of Kłodzko, a decrease in the population was observed over the years 1995-2016. Presumably, the cause of this phenomenon is the migration of people abroad, generally in order to look for a job ${ }^{5}$. Figure 9 presents the changes of population in the city of Kłodzko, together with a trend

\footnotetext{
5 The development strategy of Kłodzko county for years 2008-2015.
} 
Table 2. The values of the treatment plant reliability factor for the treated sewage

\begin{tabular}{|l|c|c|c|}
\hline $\begin{array}{c}\text { The quality indicators } \\
\text { of treated sewage }\end{array}$ & $\begin{array}{c}\text { The average value } \\
\bar{x}\left[\mathrm{mg} \cdot \mathrm{dm}^{-3}\right]\end{array}$ & $\begin{array}{c}\text { The permissible value of the quality } \\
\text { indicators in treated sewage } x_{\text {per. }} \\
{\left[\mathrm{mg} \cdot \mathrm{dm}^{-3}\right]}\end{array}$ & $\begin{array}{c}\text { The treatment plant } \\
\text { reliability factor }(R F)\end{array}$ \\
\hline $\mathrm{BOD}_{5}$ & 5.85 & 15.0 & 0.39 \\
\hline $\mathrm{COD}_{\mathrm{cr}}$ & 25.53 & 125.0 & 0.20 \\
\hline Total nitrogen & 8.53 & 15.0 & 0.57 \\
\hline Total phosphorus & 0.32 & 2.0 & 0.16 \\
\hline Total suspended solids & 10.26 & 35.0 & 0.29 \\
\hline
\end{tabular}

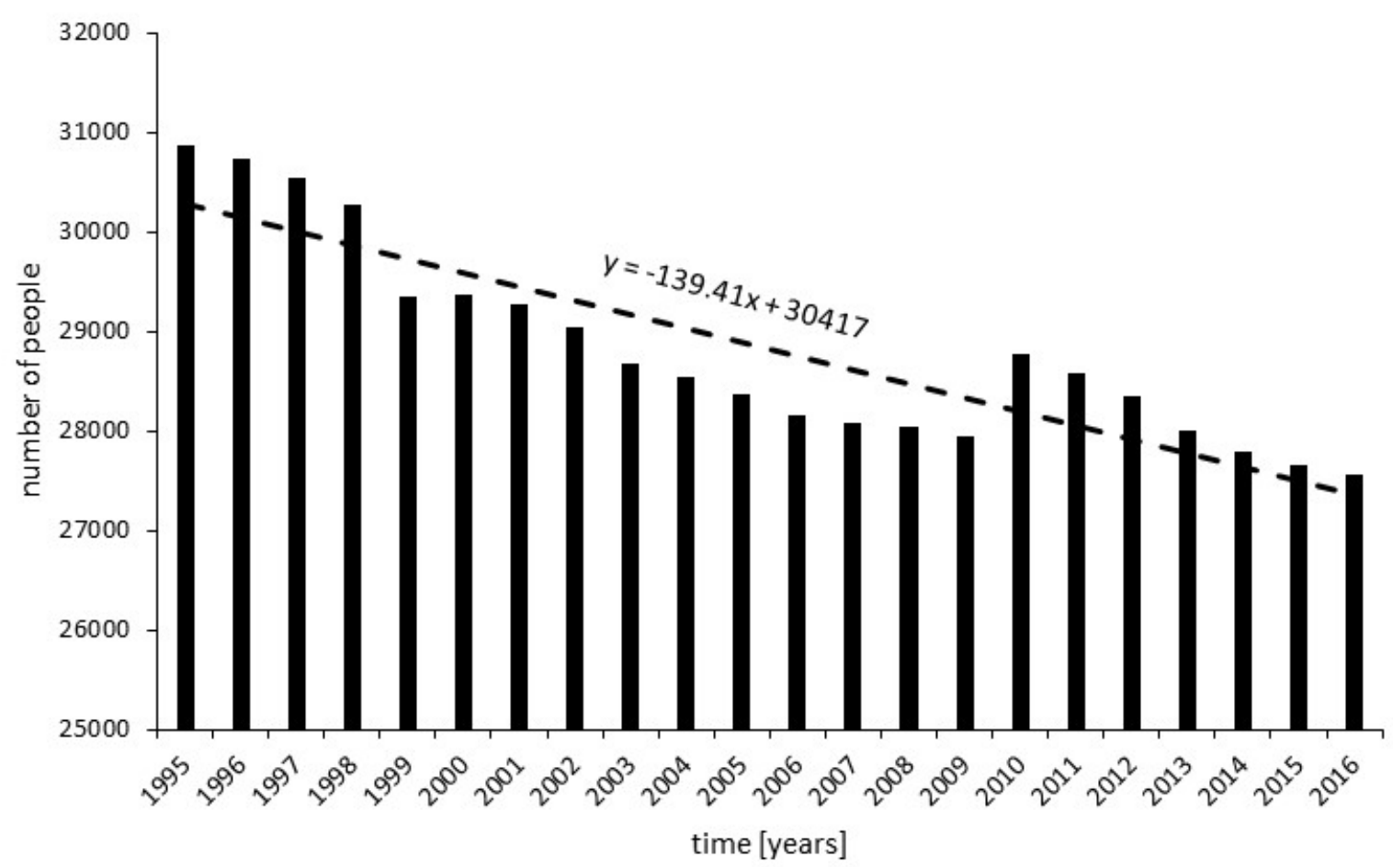

Figure 9. The changes in the number of people in the city of Kłodzko from 1995 to 2016.

line and equation that was used for the calculation of prospective population in 2036.

The annual rate of population declines, which was calculated on the basis of the trend line reached $0.52 \%$, which in 20 -years perspective, gives the $10.4 \%$ decrease of population. For the city of Kłodzko it means a decrease in the population by 2866 of people in comparison to 2016. With the current number of people which is 27554 , the prospective population in the city of Kłodzko in 2036 is estimated to equal 24688 people.

The prospective quantity of sewage was determined on the basis of the amount of sewage generated daily per capita which was calculated taking into account the average daily wastewater flows in $2016\left(5190 \mathrm{~m}^{3} \cdot \mathrm{d}^{-1}\right)$ and the number of inhabitants in the same year. The result of the calculation showed that the daily average wastewater flows per capita reached $188.36 \mathrm{dm}^{3}$. capita${ }^{1} \cdot \mathrm{d}^{-1}$. Assuming the constant value of average daily wastewater flows per capita and knowing the prospective number of people, it is easy to estimate the amount of sewage generated in 2036 , which is $4650 \mathrm{~m}^{3} \cdot \mathrm{d}^{-1}$. This value is $10.4 \%$ lower in comparison with the quantity of sewage generated in 2016 .

\section{CONCLUSIONS}

Considering the analysis of the obtained data associated with the quantity and quality of sewage, parameters of treatment plant and changes of population, it can be found that the current operation of treatment plant meets all requirements with regard to the effectiveness of pollutants removal. Taking into account that the permissible concentrations of the regulated indicators of sewage quality were exceeded, as well as the low values of the treatment plant reliability factor and 
high values of percentage reduction of the individual pollutants, it can be said the efficiency of the treatment process is high enough to contribute to the protection of waters in the receiver, and the facility does not pose a threat for the environment.

Nowadays, the WWTP works with a high reserve of performance. The actual value of $E N I$ is approximately $50 \%$ lower comparing to the assumed value. The amount of sewage, which currently flows into the treatment plants $\left(5190 \mathrm{~m}^{3} \cdot \mathrm{d}^{-}\right.$ ${ }^{1}$ ) is also significantly lower than the maximum quantity of sewage which the treatment plant is able to take. Moreover, the predictions of the number of people and the generated sewage are not optimistic (over the years, these values will decrease). Therefore, the treatment plant may have difficulties associated with providing the proper flow of sewage through the treatment system. This is particularly important for the activated sludge section, where too small flow of sewage - which additionally carries insufficient amounts of nutrients - may cause a decrease in the efficiency of biomass growth and thus a decrease in the effectiveness of the treatment process.

In order to maintain high efficiency of wastewater treatment and thereby the lowest possible operating costs, the WWTP in the city of Kłodzko, should be modernized in the future, which will reduce its current capacity. This will prevent the generation of undesirable costs and the biological treatment system will be operated under optimal conditions.

\section{Acknowledgements}

The authors wish to express the special thanks to the company "Wodociągi Kłodzkie Sp. z o.o." for providing the data necessary to create this publication.

\section{REFERENCES}

1. Al-Zahiri A. 2015. Assessment of Performance of Wastewater Treatment Plants in Jordan. International Journal of Civil and Environmental Engineering, $1-6$.

2. Arnell M. 2016. Performance Assessment of Wastewater Treatment Plants. Multi-Objective Analysis Using Plant-Wide Models. Ph.D. Thesis, Lund University, Lund, Sweden.

3. Bugajski P. 2014.Assesment of Nutrient Removal Reliability in a Sewage Treatment Plant Using the
Weibull Method. Zeszyty Problemowe Postępów Nauk Rolniczych, 576, 13-21 (in Polish).

4. Bugajski P., Mielenz B. 2008. The Assesment of Working Sewage Treatment Plant at Wadowice Before the Modernization. Infrastruktura i ekologia terenów wiejskich, 2, 129-138 (in Polish)

5. Castellet L., Molinos-Senante M. 2016. Efficiency assessment of wastewater treatment plants: A data envelopment analysis aaproach integrating technical, economic, and environmental issues. Journal of Environmental Management, 167, 160-166.

6. Ibrahim A.Q., Onyenekwe P.C., Nwaedozie I. M. 2014. An Efficiency Assessment of Lower Usuma Water Treatment Plant in Abuja Metropolis, Nigeria. IOSR Journal of Environmental Science, Toxicology and Food Technology, 8(12), 46-53.

7. Łagożny P., Maj K., Masłoń A. 2015. Technological efficiency of the wastewater treatment plant in Krosno. Archives of Waste Management and Environmental Protection, 17(2), 113-122 (in Polish).

8. Masłoń A., Tomaszek J.A. 2013.Evaluation of the Effectiveness of Wastewater Treatment Plant in Lubaczów. Czasopismo Inżynierii Lądowej, Środowiska i Architektury, 60(3/13), 209-222 (in Polish).

9. Miernik W., Wałęga A. 2006. Influence of Operation Time the Efficiency of on Effectiveness at Sewage Treatment Process in Lemna Sewage Treatment Plant. Infrastruktura i Ekologia Terenów Wiejskich, 3, 39-51 (in Polish).

10. Miksch K. Sikora J. 2010. Biotechnology of Wastwater. Wydawnictwo Naukowe PWN, Warsaw (in Polish).

11. Młyński D., Chmielowski K., Młyńska A., Miernik W. 2016a. Evaluation of Efficiency of Sewage Treatment Plant in Jasło. Infrastruktura i Ekologia Terenów Wiejskich, 1, 147-162 (in Polish).

12. Młyński D., Chmielowski K., Młyńska A. 2016b. The Assesment of the Efficiency and Stability of Work Sewage Treatment Plant in Zabajka. Inżynieria Ekologiczna, 47, 123-130 (in Polish).

13. Randall C.W., Barnard J. L., Stensel H. D.1998. Design and Retrofit of Wastewater Treatment Plants for Biological Nutrient Removal, Volume 5. CRC Press.

14. Sadecka Z.: 2010. Basics of Biological Wastewater Treatment. Wydawnictwo Seidel-Przywecki, Warsaw (in Polish).

15. Strzelczyk M., Pulikowski K., Steinhoff-Wrześniewska A., Pawęska K. 2012. An Assesment of the Efficiency of Rural Sewage Treatment in Soil-Plant System Based on Lysimetric Studied. Woda-Środowisko-Obszary Wiejskie, T.12, 4(40), 267-279 (in Polish). 